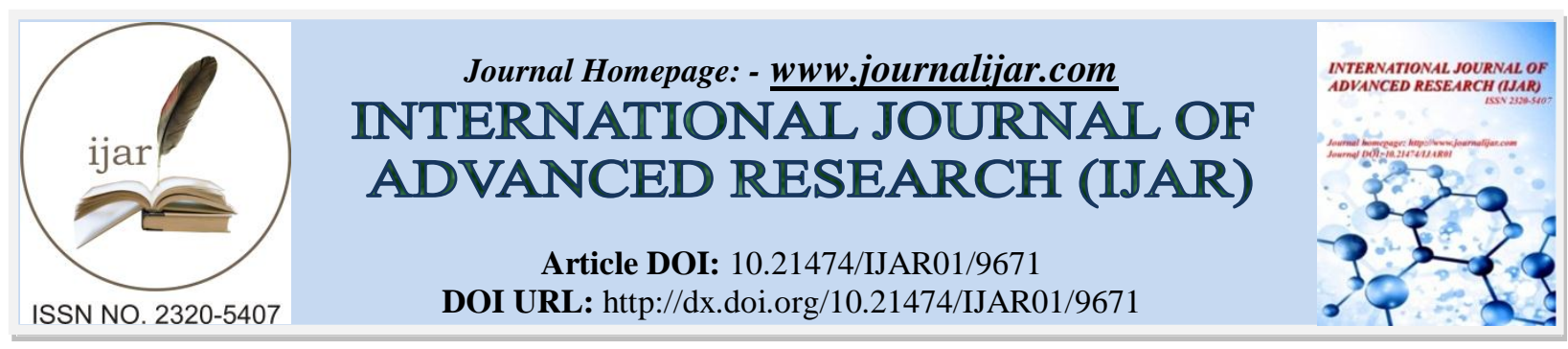

RESEARCH ARTICLE

\title{
COMBINED OPEN AND CLOSED APPROACH FOR MANAGEMENT OF PILONIDAL SINUS BY SPECIAL U-SHAPED SUTURES WITHOUT DRAIN. RANDOMIZED CONTROLLED CLINICAL TRIAL.
}

Tamer .A. A.M. Habeeb, Ashraf Goda and Osama M.H.Khalil.

Department of General Surgery, Faculty of Medicine, Zagazig University, Egypt.

\section{Manuscript Info}

Manuscript History

Received: 06 July 2019

Final Accepted: 08 August 2019

Published: September 2019

Key words:-

pilonidal sinus, combined, sutures, drain.

\section{Abstract}

Introduction: Pilonidal sinus disease (PSD) is a common surgical disease frequently seen in the intergluteal cleft. The treatment of this problem is mainly surgical.

Aim: introduce a novel technique of combined open and closed approach for management of primary pilonidal sinus (non-recurrent) by special U-shaped sutures and compare it with other techniques as regard operative time, time of complete wound healing, postoperative pain, time to stop analgesic drugs and evaluate the result of surgery without drain.

Patients: this study was conducted on 160 patients with PSD in the sacrococcygeal region who underwent operation between December 2015 and December 2017. All cases are divided randomly into four groups each consists of 40 patients.

Results: There were 160 patients, 135 males and 25 females, with a mean age of 23 years. The mean operative time was $37 \pm 10$ minutes in group $\mathrm{A}$ and group $\mathrm{D}$ while the mean operative time was $45 \pm 10$ in group B and group C. There were ten wound dehiscence, two cases occurred in each group A, C, D and four cases occurred in group B. Seroma occurred in 2 cases of Rhomboid flap technique. six patients experienced recurrence, one in each group A,B and 2 cases occurred in each group $\mathrm{C}$ and $\mathrm{D}$. pain score was low and no major complications were recorded in group A. Most wounds heal within 3-8 weeks. Four patients recurred at $7^{\text {th }}$ month and 2 cases recurred at $12^{\text {th }}$ month.

Conclusion: combined open and closed approach for management of pilonidal sinus by special U-sutures without drain is simple , minimal postoperative pain, require short a hospitalization and minimal wound care, allow a rapid return to normal activity, and have a low recurrence rate.

Copy Right, IJAR, 2019,. All rights reserved.

\section{Introduction:-}

Pilonidal sinus disease (PSD) is a common disease seen in the intergluteal cleft. This disease is usually seen between the ages of 15 years and 35 years, and males are affected more often than females [1]. The incidence of the disease is $26 / 100,000$ in the general population [2]. The most accepted theory for this disease development is the penetration of shed hair into the skin and is associated with inflammation, abscess and sinus formation [1]. The depth of the

Corresponding Author: - Tamer Alsaied Alnaimy.

Assistant Professor of General Surgery, Department of General Surgery, Faculty of medicine Zagazig 360 University, Egypt. 
intergluteal sulcus, the number of loose hair, and the stiffness of the hairs play important role in the disease etiology [3]. The reason for the wide acceptance of the acquired theory may be the high recurrence rates of up to $30 \%$ even after the most radical local excisions of pilonidal disease, which suggests that a pilonidal sinus is an acquired new disease rather than the persistence of some existing sinuses [4]. Although many medical and surgical methods have been proposed for this disease management, no clear consensus about the best method of treatment has been reported so far in the literature. Medical treatment modalities include phenol, silver nitrate, and electro cauterization of the cavity .The surgical options include excising the sinus to the level of the sacrococcygeal fascia and primary closure, or leaving it to secondary healing, Z-plasty, split-skin grafting, Rhomboid flap rotation, or Karydakis flap [5]. Eradication of the pilonidal sinus through wide surgical excision is still the cornerstone of treatment, yielding good long-term results, but at the expense of postoperative complications, prolonged hospital stay and a period of off-work up to 4-8 weeks, substantial pain, sub-optimal aesthetic results and recurrence [6].

The main problem after PSD surgery is recurrence, and recurrence rates have been reported in the literature to range from $3 \%$ to $46 \%$, depending on the technique used [7].

The aim of the present study was to analyze, evaluate and compare the short term and long term clinical results of this novel technique of combined closed and open approach for management of pilonidal sinus by special U-shaped sutures without drain, Rhomboid flap technique, Karydakis technique and open technique, an approach that allows surgeons to overcome these techniques complications.

\section{Materials and methods:-}

This is a controlled clinical trial on 160 patients who had been operated on for PSD between December 2015 and December 2017. after approval from medical ethical committee. Fifteen patients were lost during the study as we cannot reach them by any way and were excluded from the study. The remaining consecutive patients were included in this prospective analysis.

The patients were divided into 4 groups: Group A: 40 patients underwent combined open and closed technique, Group B: 40 patients underwent Rhomboid flap technique, Group C: 40 patients underwent Karydakis technique and Group D: 40 patients underwent open technique and wound is left to heal with secondary intention. Patients are grouped randomizally that patient 1 went to group A and patient 2 went to group B and patient 3 went to group c and patient 4 went to group $\mathrm{D}$ and the process is repeated.

Time of operation, postoperative morbidity and hospital stay, and loss of work days, duration of wound healing and recurrence were analyzed. Informed consent was obtained from all individual participants included in the study.

Inclusion criteria include primary PSD in intergluteal region between 18-35 years. Also those fulfilling the diagnostic criteria of Chronic discharging sinus/sinuses in natal cleft with or without surrounding tissue inflammation and with associated pain and bleeding on clinical evaluation were also included in our study.

Exclusion criteria include recurrent pilonidal sinus, patients who were terminally ill, had Uncontrolled diabetics, were Immunocompromised and immunosuppressed patients, had acute pilonidal abscess.

The patients with PSD underwent the procedure by the same surgeon. Infected sinuses were treated with antibiotics prior to the surgery for at least 2 weeks.

The patient's age, sex, operation time, mean hospital stay, postoperative wound complications, cosmetic appearance and recurrence rate, and hypoesthesia in the gluteal region were recorded during follow-up period. Clinical assessments were performed postoperatively on the 1 st day, $3^{\text {rd }}$ day, $7^{\text {th }}$ day, and $10^{\text {th }}$ day and by telephone on the $1^{\text {st }}$ month, 3rd month, 6th month, and 12th month.

\section{Operative technique}

The patients were hospitalized, and the site of the operation was shaved on the day of the surgery. All Patients were operated on under spinal anesthesia. Antibiotic was administered to all patients as prophylaxis 60 minutes prior to the surgery. An adhesive tape was used to part the buttocks. The patients were placed in the jack-knife position. (Fig. 1). Methylene blue was injected without pressure through the external opening to delineate the sinus. The operation site was cleaned with $10 \%$ povidone-iodine. All sinus tracts were resected en bloc via elliptical incision down to presacral fascia with meticulous hemostasis. (Fig 2)(Fig.3). 
Group A:The wound was closed with 0 polypropylene sutures including skin, subcutaneous tissue and including the presacral fascia starting $5 \mathrm{~cm}$ from the edge of the wound and pass to the other side $5 \mathrm{~cm}$ from the edge of the wound including presacral fascia, subcutaneous tissue and the skin. Then pass $2 \mathrm{~cm}$ from the edge of the wound and pass through the three layers to the other side in double u-shaped sutures. Multiple sutures are used according to the length of the wound. Sutures were approximated together without tension (Fig. 4-11).

Group B:Rhomboid flap technique: involve closure of the defect after excision of all sinuses with Rhomboid flap of skin and subcutaneous tissue.

Group C:Karydakis flap technique: the long axis of the ellipse is parallel to the midline and $2 \mathrm{~cm}$ from it.undercutting incision is made along the whole length $1 \mathrm{~cm}$ below the skin surface then unrolling the flap over the midline.

Group D: Open procedure involved a wide excision of the pilonidal sinus tract and healing by secondary intention.

\section{Postoperative follow-up}

Postoperative management included pressure dressings, low residual diet until the fifth postoperative day, inspection of dressings in every other day, and suture removal on the 21th postoperative day. Instructions on discharge included avoidance of prolonged sitting and riding a bicycle until 8 weeks postoperatively to prevent wound disruption, improving local hygiene and regular removal of hairs by depilatory creams.

Before discharge from hospital, patients are asked to return to the clinic on postoperative Day 3, Day 7, and Day 10. The skin sutures were removed on the 21th postoperative day. The long-term follow-up (1st month, 3rd month, 6th month, and $12^{\text {th }}$ month) was performed via outpatient interview or by telephone interview.

Successful treatment was the healing of the wound by subcutaneous scar formation and epithelization of the wound at 8-12 weeks. If skin and subcutaneous tissue reopened with discharge, it is reported as wound dehiscence. The wound that seemed to have healed within the first 8 weeks but recurred later on during the study period (either reopening of a primarily healed pit or emerging of a new one) was documented as recurrence. A visual analogue scale (VAS) score was used to assess pain.

\section{Statistical analysis:-}

Qualitative data were expressed as absolute frequencies (number) \& relative frequencies (percentage). Categorical data were compared using Chi-square test. All tests were two sided. p-value $<0.05$ was considered statistically significant. All data were collected, tabulated and statistically analyzed using SPSS 20.0 for windows (SPSS Inc., Chicago, IL, USA).

\section{Results:-}

In our study, out of total 160 patients, $85 \%(\mathrm{n}=135)$ patients were males and $15 \%(\mathrm{n}=25)$ were females.

The age distribution ranged from 18-40 years in the study, with the mean age in Group-A being 24.43 (SD \pm 6.08 ) and the mean age in Group-B was 27.40 ( $\mathrm{SD} \pm 5.90$ ), Group C was $25.4 \pm 5.3$, Group D was 28.2 \pm 4.2 .

Twelve patients $(30 \%)$ had been treated for infected pilonidal sinus. All of these patients were free of infection at the time of the operation. The mean operation time was $37 \pm 10$ minutes. The hospital stay was 1 day in most cases of group A,C and longer in group B,D. Non-steroidal anti-inflammatory drug was sufficient for pain control in most patients of group A with rapid return to work than other groups. There were no mortality in all groups. The mean follow-up period was 12 month. Wound dehiscence was observed in 10 patients (24\%), more in group B and least in group A. one had ridden on a motorcycle on the 7th day postoperatively and one received direct kick on gluteal region on $5^{\text {th }}$ postoperative day and fecal contamination was observed in the other 7 patients on the 10th postoperative day despite the recommendations given for local hygiene.

Maceration occurred in 2 patients of group A, Maceration was detected at the lower part of the incision near the anal region .all are treated conservatively. No Seroma nor hematoma in group A and group D. infection rate was lowest in group $\mathrm{A}(1 \%)$. Recurrence occurred in 6 patient (20\%).recurrent cases had previous abscess before surgery. 
Result:-

Table 1:-Demographic data.

\begin{tabular}{|c|c|c|c|c|c|c|c|c|c|}
\hline \multirow[t]{2}{*}{$\begin{array}{l}\text { Demographic } \\
\text { data }\end{array}$} & \multicolumn{2}{|c|}{$\begin{array}{c}\text { Group A } \\
(n=40)\end{array}$} & \multicolumn{2}{|c|}{$\begin{array}{c}\text { Group B } \\
(n=40)\end{array}$} & \multicolumn{2}{|c|}{$\begin{array}{c}\text { Group C } \\
(n=40)\end{array}$} & \multicolumn{2}{|c|}{$\begin{array}{c}\text { Group D } \\
(\mathrm{n}=40)\end{array}$} & \multirow[t]{2}{*}{$\begin{array}{c}\mathrm{p}- \\
\text { value }\end{array}$} \\
\hline & No. & $(\%)$ & No. & $(\%)$ & No. & $(\%)$ & No. & $(\%)$ & \\
\hline \multicolumn{10}{|l|}{ Age } \\
\hline $18-30$ years & 29 & $(73 \%)$ & 35 & $(88 \%)$ & 32 & $(80 \%)$ & 37 & $(93 \%)$ & 0.087 \\
\hline $31-40$ years & 11 & $(27 \%)$ & 5 & $(12 \%)$ & 8 & $(20 \%)$ & 3 & $(7 \%)$ & \\
\hline \multicolumn{10}{|l|}{ Sex } \\
\hline Male & 32 & $(80 \%)$ & 38 & $(95 \%)$ & 36 & $(90 \%)$ & 29 & $(73 \%)$ & 0.026 \\
\hline Female & 8 & $(20 \%)$ & 2 & $(5 \%)$ & 4 & $(10 \%)$ & 11 & $(27 \%)$ & \\
\hline
\end{tabular}

Categorical variables were expressed as number (percentage); $\ddagger$ Chi-square test; $\mathrm{p}<0.05$ is significant.

Table 2:-Preoperative data.

\begin{tabular}{|c|c|c|c|c|c|c|c|c|c|}
\hline \multirow[t]{2}{*}{$\begin{array}{l}\text { Preoperative } \\
\text { data }\end{array}$} & \multicolumn{2}{|c|}{$\begin{array}{c}\text { Group A } \\
(n=40)\end{array}$} & \multicolumn{2}{|c|}{$\begin{array}{c}\text { Group B } \\
(n=40)\end{array}$} & \multicolumn{2}{|c|}{$\begin{array}{c}\text { Group C } \\
(\mathrm{n}=40)\end{array}$} & \multicolumn{2}{|c|}{$\begin{array}{c}\text { Group D } \\
(\mathrm{n}=40)\end{array}$} & \multirow[t]{2}{*}{$\begin{array}{c}\text { p- } \\
\text { valuet }\end{array}$} \\
\hline & No. & $(\%)$ & No. & $(\%)$ & No. & $(\%)$ & No. & $(\%)$ & \\
\hline \multicolumn{10}{|l|}{ Abscess } \\
\hline Present & 5 & $(13 \%)$ & 1 & $(2.5 \%)$ & 2 & $(5 \%)$ & 4 & $(10 \%)$ & 0.307 \\
\hline Absent & 35 & $(87 \%)$ & 39 & $(97.5 \%)$ & 38 & $(95 \%)$ & 36 & $(90 \%)$ & \\
\hline
\end{tabular}

Categorical variables were expressed as number (percentage); $\ddagger$ Chi-square test; $\mathrm{p}<0.05$ is significant.

Table 3:-Intraoperative data.

\begin{tabular}{|c|c|c|c|c|c|c|c|c|c|}
\hline \multirow[t]{2}{*}{$\begin{array}{l}\text { Intraoperative } \\
\text { data }\end{array}$} & \multicolumn{2}{|c|}{$\begin{array}{c}\text { Group A } \\
(\mathrm{n}=40)\end{array}$} & \multicolumn{2}{|c|}{$\begin{array}{c}\text { Group B } \\
(\mathrm{n}=40)\end{array}$} & \multicolumn{2}{|c|}{$\begin{array}{c}\text { Group C } \\
(\mathrm{n}=40)\end{array}$} & \multicolumn{2}{|c|}{$\begin{array}{c}\text { Group D } \\
(\mathrm{n}=40)\end{array}$} & \multirow[t]{2}{*}{$\begin{array}{c}\mathrm{p}- \\
\text { value }\end{array}$} \\
\hline & No. & $(\%)$ & No. & $(\%)$ & No. & $(\%)$ & No. & $(\%)$ & \\
\hline \multicolumn{10}{|l|}{ Operative time } \\
\hline $30-35 \mathrm{~min}$ & 16 & $(40 \%)$ & 10 & $(25 \%)$ & 15 & $(37.5 \%)$ & 34 & $(85 \%)$ & $<0.001$ \\
\hline $36-50 \mathrm{~min}$ & 24 & $(60 \%)$ & 30 & $(75 \%)$ & 25 & $(62.5 \%)$ & 6 & $(15 \%)$ & \\
\hline
\end{tabular}

Categorical variables were expressed as number (percentage); $\$$ Chi-square test; $\mathrm{p}<0.05$ is significant.

Table 4:-Postoperative data.

\begin{tabular}{|c|c|c|c|c|c|c|c|c|c|}
\hline \multirow[t]{2}{*}{$\begin{array}{l}\text { Postoperative } \\
\text { data }\end{array}$} & \multicolumn{2}{|c|}{$\begin{array}{c}\text { Group A } \\
(\mathrm{n}=40)\end{array}$} & \multicolumn{2}{|c|}{$\begin{array}{l}\text { Group B } \\
(n=40)\end{array}$} & \multicolumn{2}{|c|}{$\begin{array}{c}\text { Group C } \\
(\mathrm{n}=40)\end{array}$} & \multicolumn{2}{|c|}{$\begin{array}{c}\text { Group D } \\
(\mathrm{n}=40)\end{array}$} & \multirow[t]{2}{*}{$\begin{array}{c}\mathrm{p}- \\
\text { value }+\end{array}$} \\
\hline & No. & $(\%)$ & No. & $(\%)$ & No. & $(\%)$ & No. & $(\%)$ & \\
\hline \multicolumn{10}{|l|}{ LOS } \\
\hline 1 day & 37 & $(93 \%)$ & 6 & $(15 \%)$ & 32 & $(80 \%)$ & 20 & $(50 \%)$ & $<0.001$ \\
\hline 2-3 days & 3 & $(7 \%)$ & 34 & $(85 \%)$ & 8 & $(20 \%)$ & 20 & $(50 \%)$ & \\
\hline \multicolumn{10}{|l|}{$\begin{array}{l}\text { Analgesic } \\
\text { intake }\end{array}$} \\
\hline 1-3 days & 26 & $(65 \%)$ & 8 & $(20 \%)$ & 20 & $(50 \%)$ & 14 & $(35 \%)$ & 0.001 \\
\hline 4-5 days & 10 & $(25 \%)$ & 18 & $(45 \%)$ & 12 & $(30 \%)$ & 20 & $(50 \%)$ & \\
\hline$>5$ days & 4 & $(10 \%)$ & 14 & $(35 \%)$ & 8 & $(20 \%)$ & 6 & $(15 \%)$ & \\
\hline \multicolumn{10}{|l|}{ Healing time } \\
\hline Up to 21 days & 35 & $(88 \%)$ & 18 & $(45 \%)$ & 8 & $(20 \%)$ & 12 & $(30 \%)$ & $<0.001$ \\
\hline$>21$ days & 5 & $(12 \%)$ & 22 & $(55 \%)$ & 32 & $(80 \%)$ & 28 & $(70 \%)$ & \\
\hline \multicolumn{10}{|l|}{$\begin{array}{l}\text { Time to return } \\
\text { to work }\end{array}$} \\
\hline Within 2weeks & 32 & $(80 \%)$ & 16 & $(40 \%)$ & 10 & $(25 \%)$ & 8 & $(20 \%)$ & $<0.001$ \\
\hline$>2$ weeks & 8 & $(20 \%)$ & 24 & $(60 \%)$ & 30 & $(75 \%)$ & 32 & $(80 \%)$ & \\
\hline \multicolumn{10}{|l|}{ Primary success } \\
\hline Yes & 35 & $(88 \%)$ & 35 & $(88 \%)$ & 34 & $(85 \%)$ & 35 & $(88 \%)$ & 0.983 \\
\hline No & 5 & $(12 \%)$ & 5 & $(12 \%)$ & 6 & $(15 \%)$ & 5 & $(12 \%)$ & \\
\hline Drain removed & & & & & & & & & \\
\hline
\end{tabular}




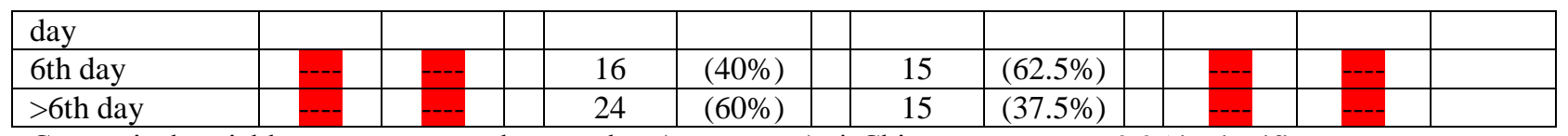

Categorical variables were expressed as number (percentage); $\ddagger$ Chi-square test; $\mathrm{p}<0.05$ is significant.

Table 5:-Complications.

\begin{tabular}{|c|c|c|c|c|c|c|c|c|c|}
\hline \multirow[t]{2}{*}{ Complications } & \multicolumn{2}{|c|}{$\begin{array}{c}\text { Group A } \\
(\mathrm{n}=40)\end{array}$} & \multicolumn{2}{|c|}{$\begin{array}{c}\text { Group B } \\
(\mathrm{n}=40)\end{array}$} & \multicolumn{2}{|c|}{$\begin{array}{c}\text { Group C } \\
(\mathrm{n}=40)\end{array}$} & \multicolumn{2}{|c|}{$\begin{array}{c}\text { Group D } \\
(\mathrm{n}=40)\end{array}$} & \multirow[t]{2}{*}{$\begin{array}{c}\mathrm{p}- \\
\text { value }\end{array}$} \\
\hline & No. & $(\%)$ & No. & $(\%)$ & No. & $(\%)$ & No. & $(\%)$ & \\
\hline \multicolumn{10}{|l|}{ Hyposthesia } \\
\hline Present & 14 & $(35 \%)$ & 28 & $(70 \%)$ & 7 & $(17.5 \%)$ & 10 & $(25 \%)$ & $<0.001$ \\
\hline Absent & 26 & $(65 \%)$ & 12 & $(30 \%)$ & 33 & $(82.5 \%)$ & 30 & $(75 \%)$ & \\
\hline \multicolumn{10}{|l|}{$\begin{array}{l}\text { Wound } \\
\text { dehiscence }\end{array}$} \\
\hline Present & 1 & $(2.5 \%)$ & 4 & $(10 \%)$ & 2 & $(5 \%)$ & 2 & $(5 \%)$ & 0.524 \\
\hline Absent & 39 & $(97.5 \%)$ & 36 & $(90 \%)$ & 38 & $(95 \%)$ & 38 & $(95 \%)$ & \\
\hline \multicolumn{10}{|l|}{ Maceration } \\
\hline Present & 2 & $(5 \%)$ & 3 & $(7.5 \%)$ & 4 & $(10 \%)$ & 8 & $(20 \%)$ & 0.140 \\
\hline Absent & 38 & $(95 \%)$ & 37 & $(92.5 \%)$ & 36 & $(90 \%)$ & 32 & $(80 \%)$ & \\
\hline \multicolumn{10}{|l|}{ Seroma } \\
\hline Present & 0 & $(0 \%)$ & 2 & $(5 \%)$ & 4 & $(10 \%)$ & 0 & $(0 \%)$ & 0.054 \\
\hline Absent & 40 & $(100 \%)$ & 38 & $(95 \%)$ & 36 & $(90 \%)$ & 40 & $(100 \%)$ & \\
\hline \multicolumn{10}{|l|}{ Hematoma } \\
\hline Present & 0 & $(0 \%)$ & 3 & $(7.5 \%)$ & 4 & $(10 \%)$ & 0 & $(0 \%)$ & 0.054 \\
\hline Absent & 40 & $(100 \%)$ & 37 & $(92.5 \%)$ & 36 & $(90 \%)$ & 40 & $(100 \%)$ & \\
\hline \multicolumn{10}{|l|}{ Infection } \\
\hline Present & 1 & $(2.5 \%)$ & 2 & $(5 \%)$ & 2 & $(5 \%)$ & 5 & $(12.5 \%)$ & 0.279 \\
\hline Absent & 39 & $(97.5 \%)$ & 38 & $(95 \%)$ & 38 & $(95 \%)$ & 35 & $(87.5 \%)$ & \\
\hline \multicolumn{10}{|l|}{ Recurrence } \\
\hline Present & 1 & $(2.5 \%)$ & 1 & $(2.5 \%)$ & 2 & $(5 \%)$ & 2 & $(5 \%)$ & 0.874 \\
\hline Absent & 39 & $(97.5 \%)$ & 39 & $(97.5 \%)$ & 38 & $(95 \%)$ & 38 & $(95 \%)$ & \\
\hline
\end{tabular}

Categorical variables were expressed as number (percentage); $\ddagger$ Chi-square test; $\mathrm{p}<0.05$ is significant.

\section{Discussion:-}

There is still no consensus about treatment of pilonidal sinus disease. Ideally, therapy should be associated with short hospital stay, less painful postoperative time, rapidly healing and return to work, less painful dressing of wound, short term wound care and a low recurrence rate. No techniques fulfill all of these criteria. We compared our results with other studies to estimate the reliability of our data.

Pilonidal sinus is more common in male [8]. In our study, male predominate than female (out of the total 160 patients $85 \%$ were males and $15 \%$ were females). Men are more affected thanks to their natural hirsutism.Most patients were young with the mean age in Group-A being 24.43 (SD \pm 6.08 ) and the mean age in Group-B was 27.40 (SD \pm 5.90$)$, Group C was $25.4 \pm 5.3$, Group D was 28.2 \pm 4.2 . . Comparable results were shown in other similar studies [17].

Acute pilonidal abscess should be treated by incision and drainage. In the present study the patients presenting with an acute abscess in the sacrococcygeal region in 12 cases that were initially treated with incision and drainage then postoperatively they were treated by third generation cephalosporin and metronidazole for 10 days. Patients were scheduled for our technique after 15-30 days.

In a prospective randomized study performed on 50 patients and divided into two equal groups: drained and nondrained. Fluid collections were encountered in two patients $(8 \%)$ of the drained group compared with eight patients $(32 \%)$ in the no drained group with the difference being statistically significant [9].In our study, absence of wound collection, Seroma and hematoma in Group A and Group D are due to wide drainage by our special sutures 
technique and the use of third generation cephalosporin antibiotics, choosing non-infected pilonidal disease in most of cases.

A controlled study showed that wound problems, length of hospital stay, morbidity, and recurrence rates did not increase in the absence of postoperative draining of the cavity. Another study also demonstrated that drain placement after rhomboid excision and Limberg flap technique might negatively affect the postoperative complication rate, although the mean operation time was significantly longer in the non-drained group [10].In our study, we did not use drain in group A and the results showed decreased hospital stay, no Seroma nor hematoma , very low recurrence rate $(2.5 \%)$ and infection occurred in one patient $(2.5 \%)$.

In group A: most patients stopped analgesic drug on postoperative 3 days. Our patients started to sit on chair without pain on postoperative 10 days .It may result from low tension in the wound.

Primary closure technique's operation time is short but has significant postoperative morbidity as wound infection rate is $12-32.7 \%$, dehiscence rate is $10-50 \%$ and recurrence rate is 5-12\% [11]. In this study, Group A showed infection in one patient $(2.5 \%)$ and the recurrence rate was low $(2.5 \%)$.

Incision and curettage, unroofing, curettage and excision with marsupialization procedures are common used surgical techniques. But these procedures had painful postoperative time, delayed healing and return to work, painful dressing of wound and long term wound care. But they have a low recurrence rate [12]. In this study, postoperative pain was low on pain scale, rapid wound healing, rapid return to work, and painless dressings and in addition, low recurrence rate $(1 \%)$

When the midline lateralized or flattened, recurrences are less likely to occur [10].In our study there is partial flattening of the intergluteal cleft, and so the recurrence rate was low $(2.5 \%)$.

Hospital stay varied from 2 to 5 days [13]. Using wide-excision techniques and median time off work was reported from 19 up to 38 days [14]. Other studies reported a mean length of hospital stay 2-4 days [9]. In the present study the length of hospital stay was 1 day in most cases of Group A and Group C.

The incidence of wound infection was ranged from $0 \%$ to $12 \%$ [15]. In our study, Group A showed Wound infection in one patient and Seroma did not occur in any patients.

Gupta [16] reported recurrence rates of $13 \%$ using wide-excision techniques, while other studies achieved $5 \%$ in larger trials [17]. A recurrence rate of $3-10 \%$ is described for excision with marsupialization of the wound [18]. Reconstructive flaps according to Limberg's technique come with a recurrence rate of 0-6\% [13] in prospective randomized studies.

In classic Limberg flap technique recurrence rate is 1.26-5.3\% [19]. In our study, Follow up time is 12 months and recurrence rate was in one case only $(2.5 \%)$. Some studies have shown that, in addition to a good surgical technique, elimination of preventable risk factors such as hygiene at the intergluteal sulcus is important to prevent recurrence [20] [21].Therefore, patients in this study were advised regarding the importance of local hygiene.

Primary closure of the wound after excision of the pilonidal sinus is associated with a high recurrence rate. In the literature, the recurrence rate after primary closure has ranged from $4 \%$ to $25 \%$ [21].

A common complaint after flap surgery was hypoesthesia on the flap, in our study hypothesia occurred in 59 cases $(37 \%)$.

Considering the problems of our study, there are two issues that have to be respected when interpreting our results: First, the recurrence rate of this study might be higher than demonstrated in the result due to shorter of follow up period and missing patients in the follow up period. Second, the wound healing time might have been shorter than it is reported in this study. The wound healing time was assessed by the patients themselves and was not determined by a physician. The wound healing time might more reflect the disappearance of any discomfort at the intergluteal fold than the complete closure of the skin after surgery. 


\section{Conclusion:-}

The results of the current study showed that the combined open and closed technique without the use of a drain with special U-shaped sutures is an effective method for the treatment of uncomplicated PSD because of lower recurrence and absent wound site complication, shorter operation time, and shorter length of hospital stay.

This study needs more evaluation on larger number of patients and follow up for longer time and evaluates its effectiveness on recurrent pilonidal sinus.

\section{Funding:}

This research did not receive any specific grant from funding agencies in the public, commercial, or not-for-profit sectors.

\section{Conflict of interest:}

None declared.

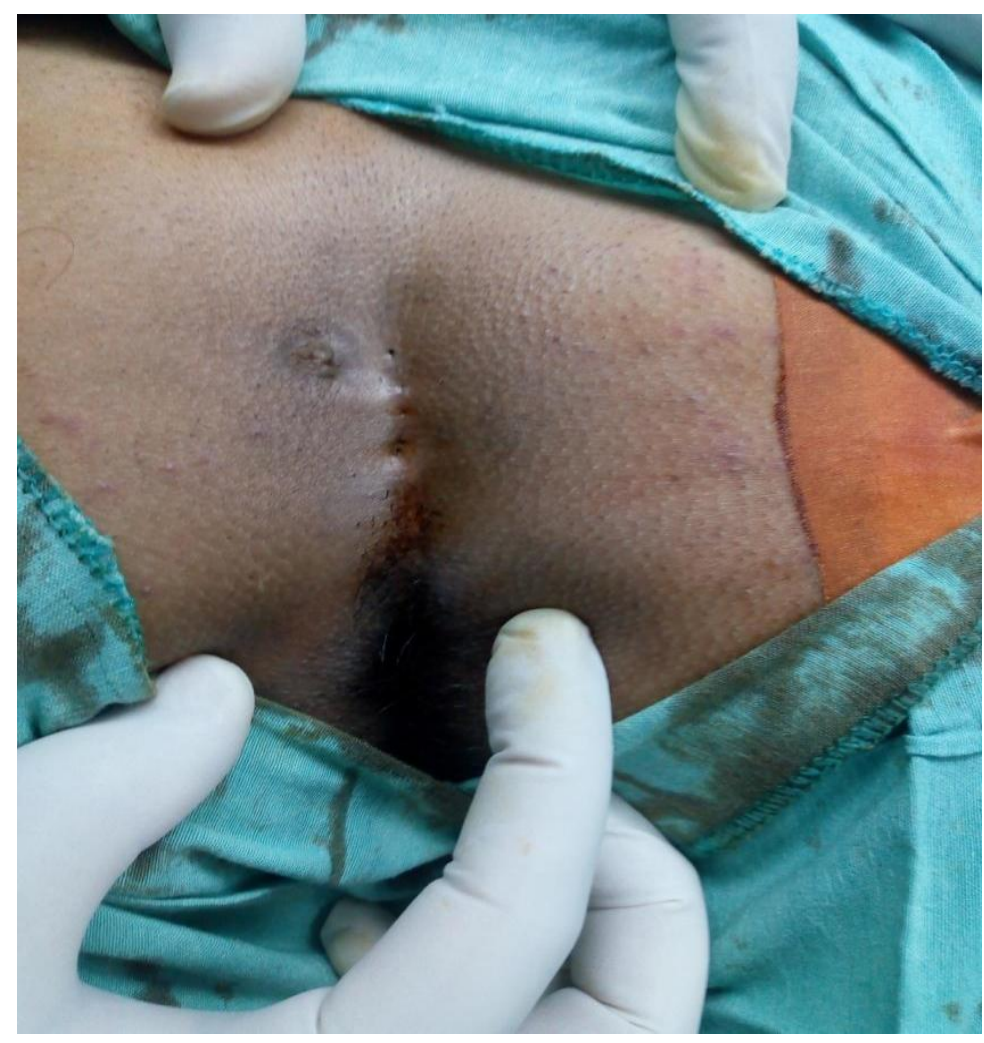

Pic 1:-pilonidal sinus in intergluteal cleft 


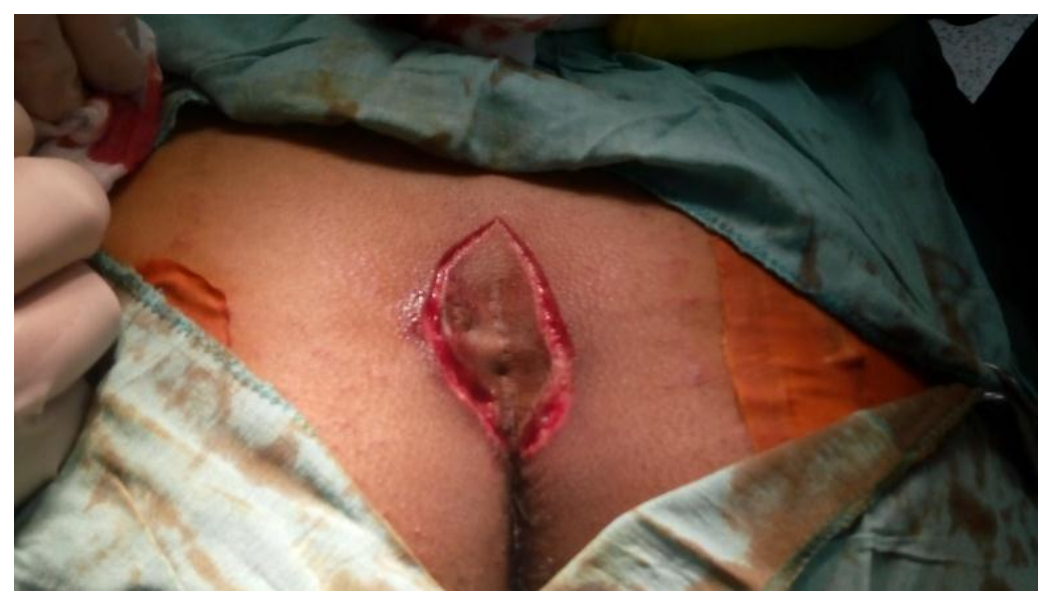

Pic 2:-elliptical incision including all sinuses

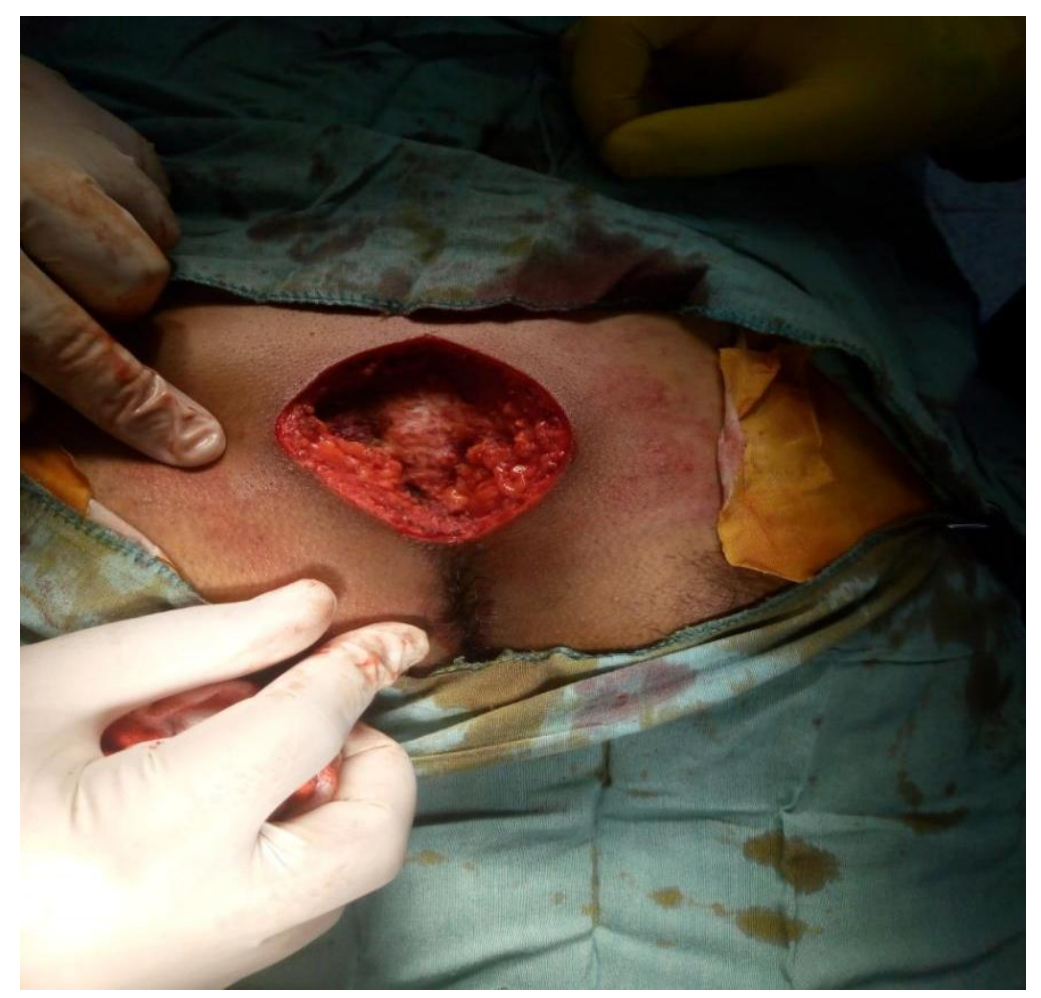

Pic 3:-complete excision of all sinuses down to presacral fascia 


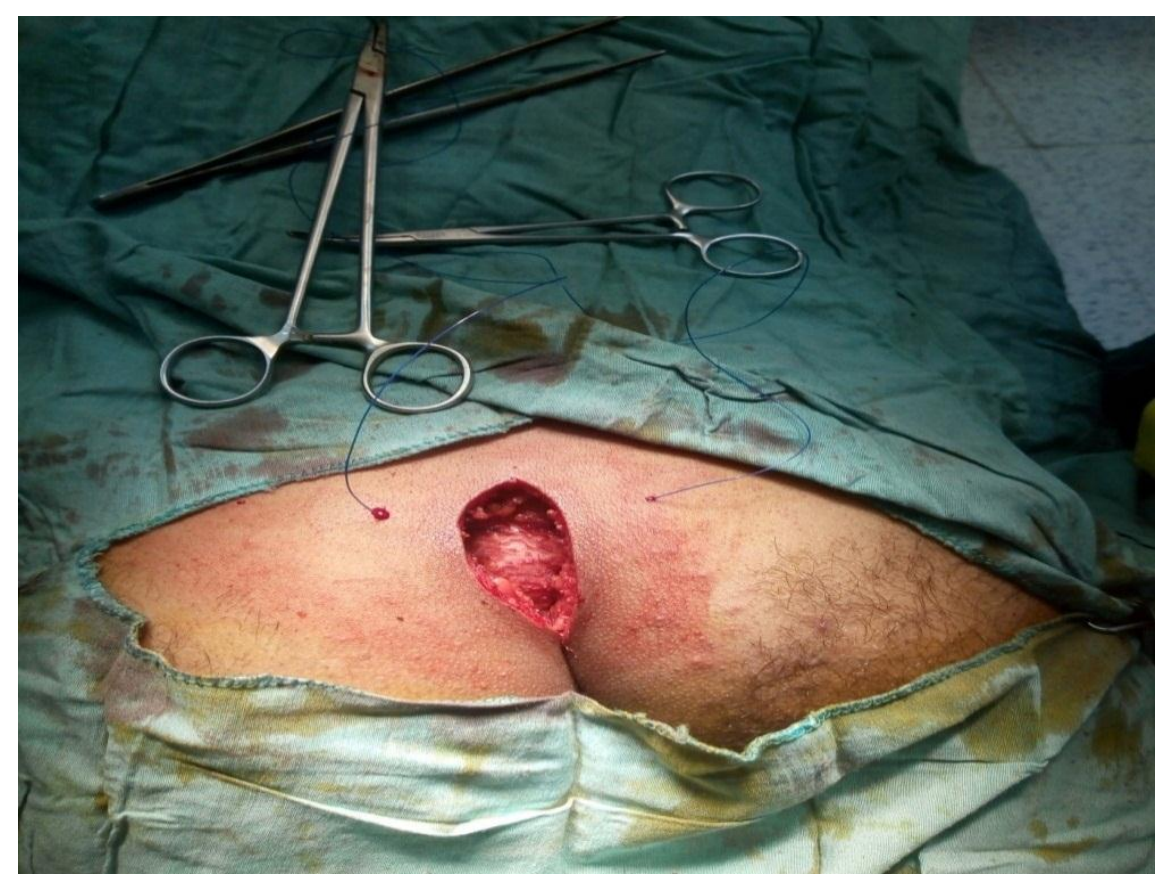

Pic 4:-prolene sutures are used to close the wound

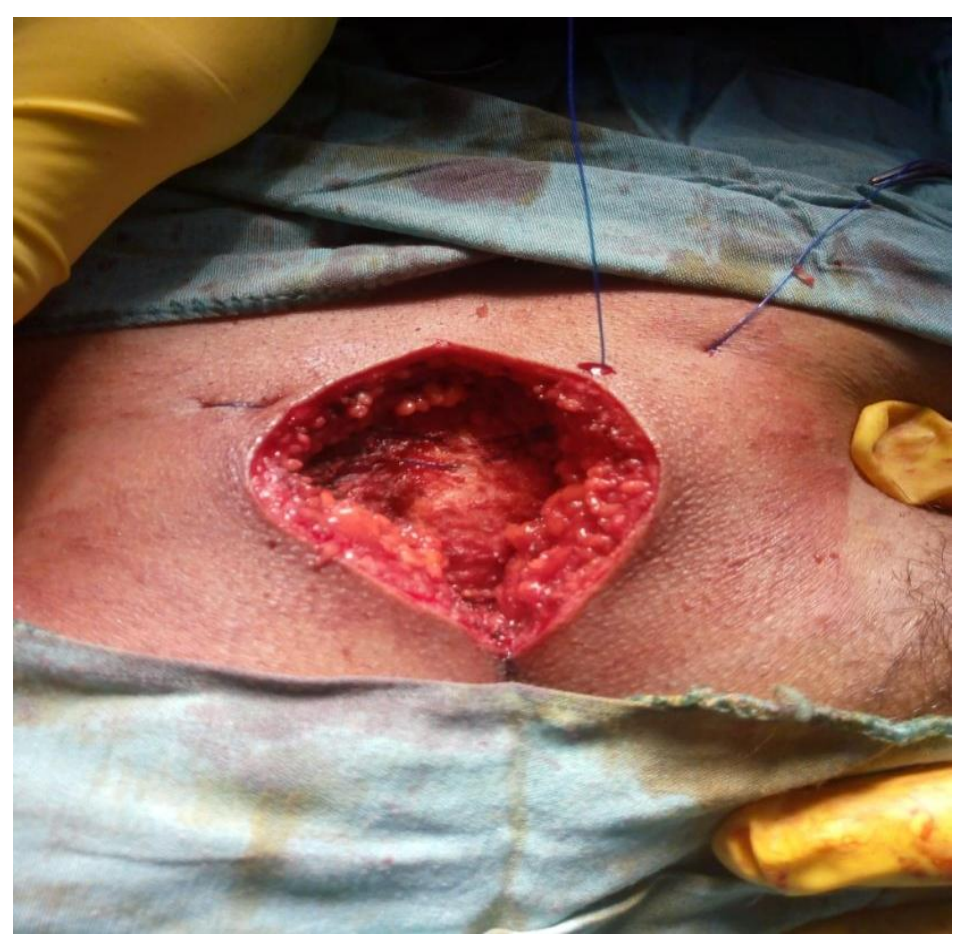

Pic 5:-u-shaped suture 


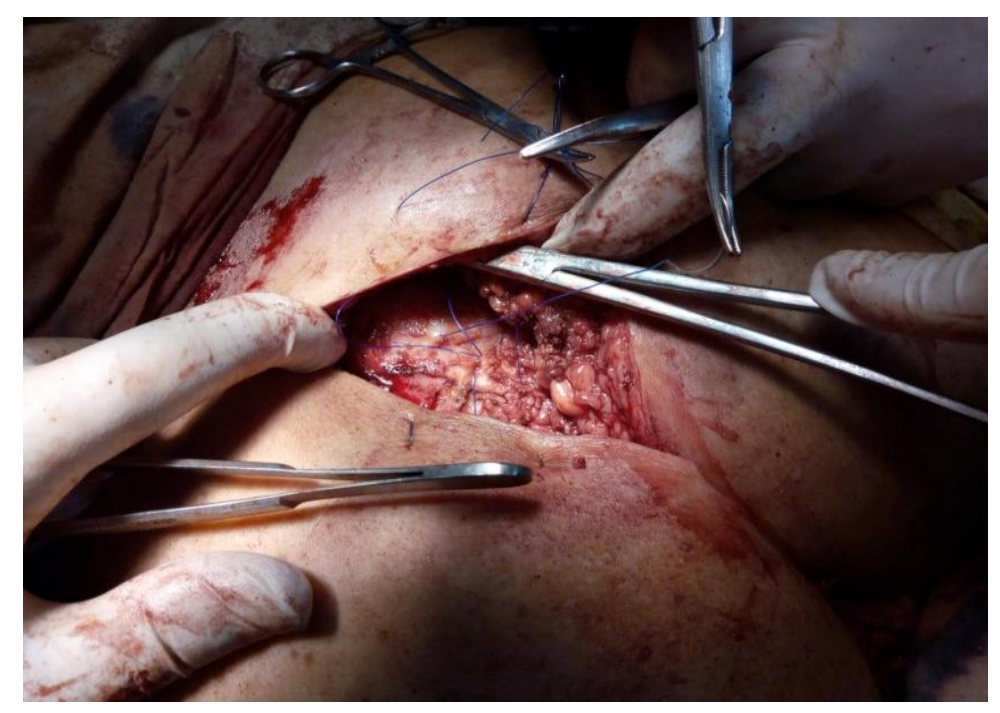

Pic 6: u-shaped suture must include presacral fascia

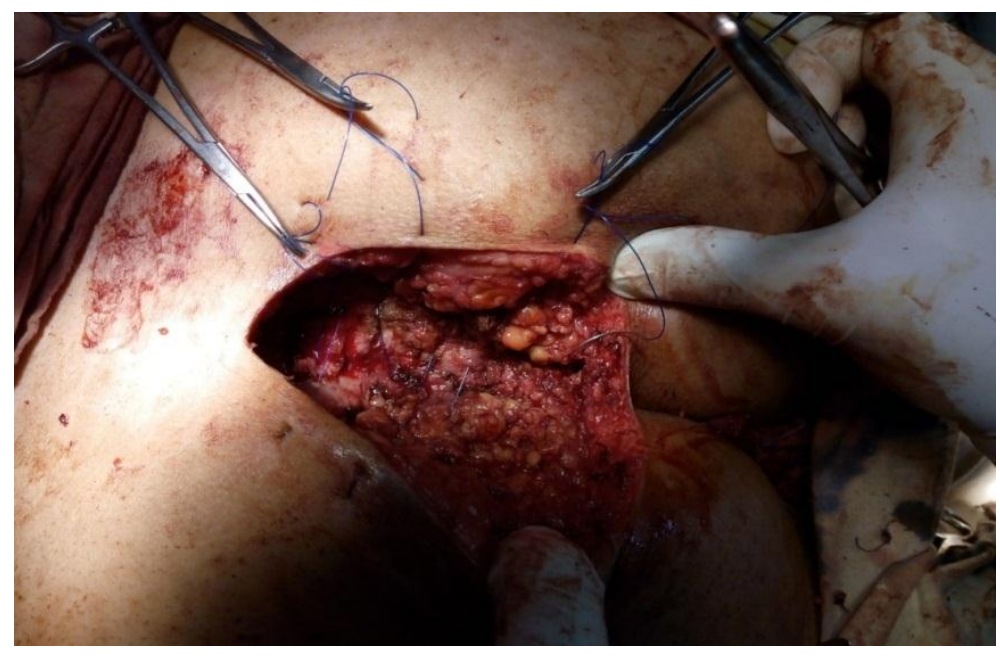

Pic 7:-u-shaped suture must include presacral fascia (another patient) 


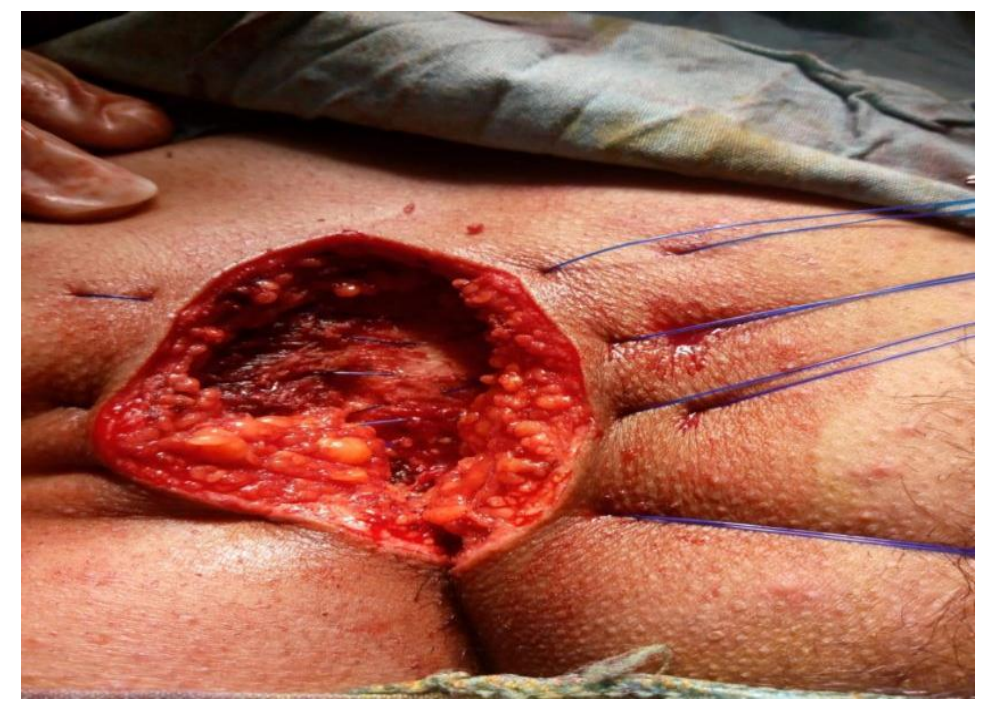

Pic 8:-four U-shaped sutures are usually sufficient for many cases.।

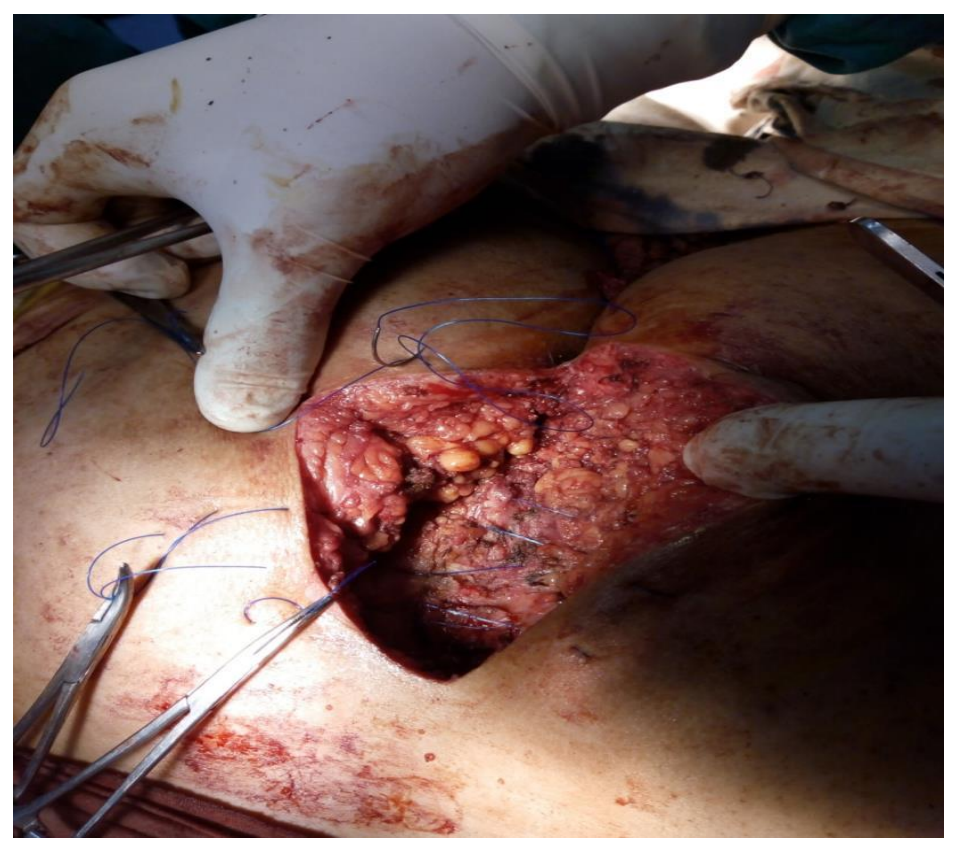

Pic 9:-ensure good hemostasis and chock the four U-shaped sutures before closure. 


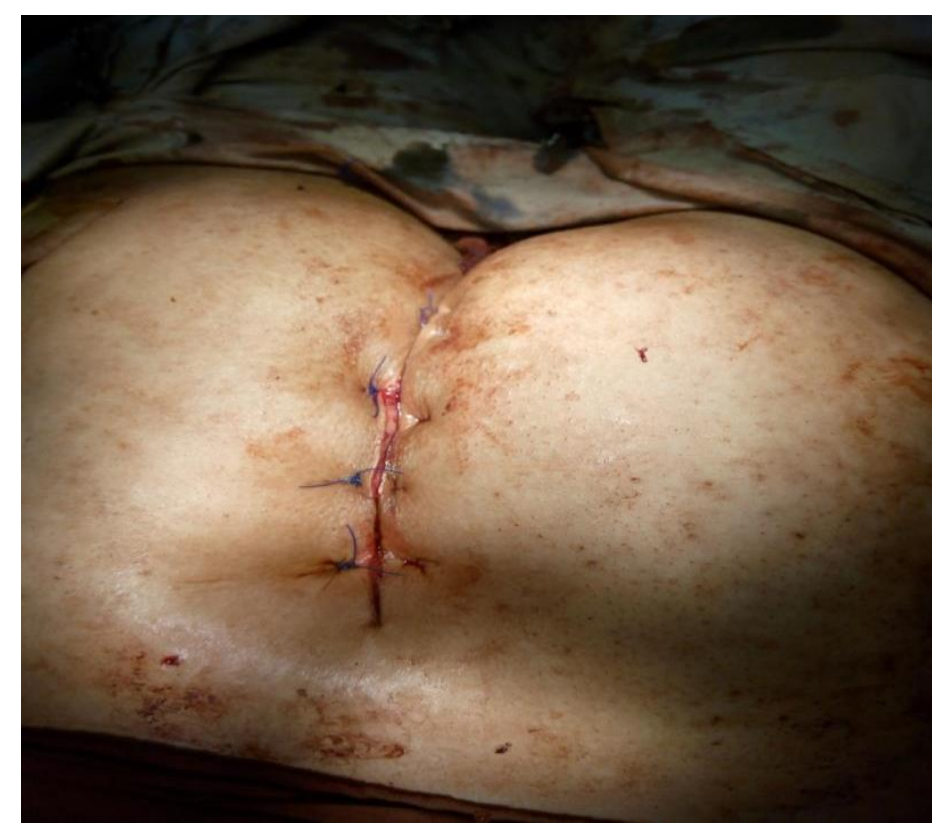

Pic 10:-the sutures are approximated and the wound is close dnote flattening of the natal cleft and the skin flap is not closed under tension

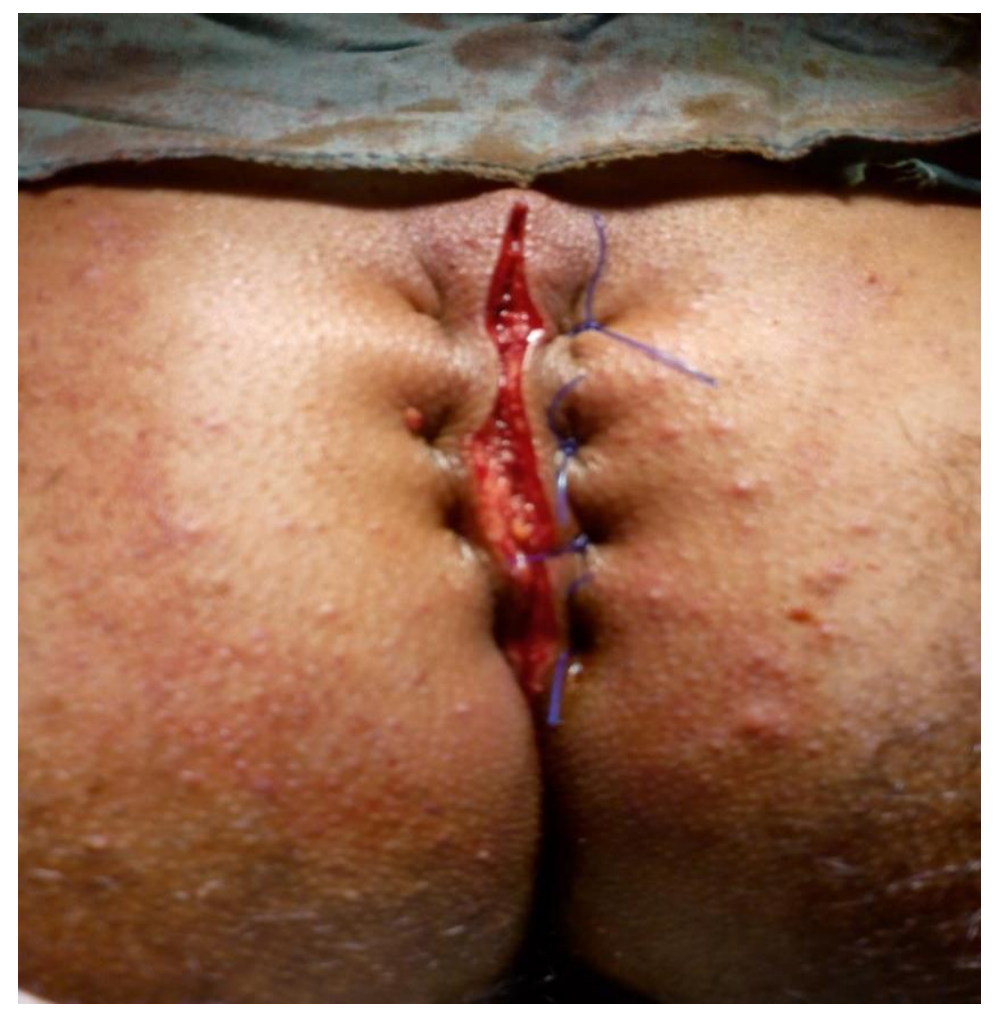

Pic 11:-the sutures are approximated and the wound is closednote flattening of the natal cleft and the skin flap is not closed under tension (another patient)

\section{Reference:-}

1. McCallum I, King PM, Bruce J. Healing by primary versus secondary intention after surgical treatment for pilonidal sinus. Cochrane Database Syst Rev. 2007; 17:CD006213. 
2. Soendenaa K, Andersen E, Nesvik I, Søreide JA. Patient characteristics and symptoms in chronic pilonidal sinus disease. Int J Colorectal Dis. 1995; 10:39-42.

3. Harlak A, Mentes O*, Kilic S, et al. Sacrococcygeal pilonidal disease: analysis of previously proposed risk factors. Clinics (Sao Paulo). 2010; 65:125-131.

4. Petersen S, Koch R, Stelzner S, et al. Primary closure techniques in chronic pilonidal sinus: a survey of the result of different surgical approaches. Dis Colon Rectum. 2002; 45:1458-1462.

5. Karydakis GE. Easy and successful treatment of pilonidal sinus after explanation of its causative processes. Aust NZ J Surg.1992; 62:385-389.

6. Shabbir J, Chaudhary BN, Britton DC (2011) Management of sacrococcygeal pilonidal sinus disease: a snapshot of current practice.Int J Colorectal Dis 26(12):1619-1620

7. Shafik A. Electrocauterization in the treatment of pilonidal sinus. Int Surg. 1996; 81:83-84.

8. Blendewald FP, Cima RR. Pilonidal disease. Clin Colon RectalSurg. 2007;20:86-95.

9. Can MF, Sevinc MM, Hancerliogullari O, Yilmaz M, Yagci G. Multicenter prospective randomized trial comparing modified Limberg flap transposition and Karydakis flap reconstruction in patients with sacrococcygeal pilonidal disease. American Journal of Surgery 2010 Sep; 200(3):318-27.Epub 2010 Feb 1.

10. Mentes BB, Leventoglu S, Cihan A, et al. Modified Limberg transposition flap for sacrococcygeal pilonidal sinus. Surg Today. 2004; 34:419-423.

11. Can MF, Sevinc MM, Yilmaz M. Comparison of Karydakis flap reconstruction versus primary midline closure in sacrococcygeal pilonidal disease: results of 200 military service members. Surgical Today 2009; 39(7):5806. Epub 2009 Jun 28.

12. Silva JH. Pilonidal cyst: cause and treatment. Diseases of the Colon \& Rectum 2000;43:1146-56.

13. Akca T, Colak T, Ustunsoy B, Kanik A, Aydin S (2005) Randomized clinical trial comparing primary closure with the Limberg flap in the treatment of primary sacrococcygeal pilonidal disease. Br J Surg 92:1081-1084

14. Perruchoud C, Vuilleumier H, Givel JC (2002) Pilonidal sinus: how to choose between excision and open granulation versus excision and primary closure? Study of a series of 141 patients operated on from 1991 to 1995. Swiss Surg 8:255-258.

15. Bessa SS. Results of the lateral advancing flap operation (modified Karydakis procedure) for the management of pilonidal sinus disease. Diseases of the Colon \& Rectum 2007 Nov; 50(11):1935-40. Epub 2007 Sep 8.

16. Gupta PJ (2005) Comparative study between radiofrequency sinus excision and open excision in sacrococcygeal pilonidal sinus disease. Dig Surg 22:459-463.

17. Sondenaa K, Nesvik I, Andersen E, Soreide JA (1996) Recurrent pilonidal sinus after excision with closed or open treatment: final result of a randomised trial. Eur J Surg 162:237-240.

18. Gencosmanoglu R, Inceoglu R (2005) Modified lay-open (incision, curettage, partial lateral wall excision and marsupialization) versus total excision with primary closure in the treatment of chronic sacrococcygeal pilonidal sinus: a prospective, randomized clinical trial with a complete two-year follow-up. Int J Colorectal Dis 20:415-422.

19. Müller K, Marti L, Tarantino I, Jayne DG, Wolff K, Hetzer FH. Prospective analysis of cosmesis, morbidity, and patient satisfaction following Limberg flap for the treatment of sacrococcygeal pilonidal sinus. Diseases of the Colon \&Rectum 2011 Apr;54(4):487-94.

20. Conroy FJ, Kandamany N, Mahaffey PJ. Laser depilation and hygiene: preventing recurrent pilonidal sinus disease. J Plast Reconstr Aesthet Surg. 2008;61:1069-1072.

21. Odili J, Gault D. Laser depilation of the natal cleft: an aid to healing the pilonidal sinus. Ann R Coll Surg Engl. 2002;84:29-32. 